\title{
Observation of organic matters concentrations in agricultural runoff in the Red River Delta (Vietnam)
}

\author{
Quan trắc hàm lượng chất hữu cơ trong nước chảy tràn từ canh tác nông nghiệp trong vùng \\ đồng bằng sông Hồng
}

LE, Nhu Da ${ }^{1,2} ;$ LE, Thi Phuong Quynh1,2*; DUONG, Thi Thuy ${ }^{3}$

'Institute of Natural Product Chemistry (INPC), VAST, 18 Hoang Quoc Viet, Cau Giay, Hanoi, Vietnam; ${ }^{2}$ Graduate University of Science and Technology, (VAST), 18 Hoang Quoc Viet, Cau Giay, Ha Noi, Vietnam; IInstitute of Environmental Technology (IET), VAST, 18 Hoang Quoc Viet, Cau Giay, Ha Noi, Vietnam

\begin{abstract}
Due to utilization increase of chemical fertilizers and manures and of a large water volume for irrigation, agricultural runoff has significantly accelerated water pollution. The Red River locates in Vietnam where agriculture plays an important role in the country's economic development. This paper presents the observation results of total organic carbon (TOC), including dissolved organic carbon (DOC) and particulate organic carbon (POC) concentrations in agricultural runoff from different plant fields (vegetable, flower, and rice) in the Red River Delta in 2013 -2014. The results showed that DOC concentrations varied in a high range from $1.0 \mathrm{mg} . \mathrm{L}^{-1}$ to $37.1 \mathrm{mg} . \mathrm{L}^{-1}$, averaging $10.2 \pm 6.2 \mathrm{mg} \cdot \mathrm{L}^{-1}$ whereas POC concentrations fluctuated from 0.5 to $4.5 \mathrm{mg}^{\mathrm{L}} \mathrm{L}^{-1}$, averaging $1.7 \pm 0.7 \mathrm{mg}^{-\mathrm{L}^{-1}}$ for 104 water samples observed. TOC concentrations in water from the vegetable and flower fields $\left(11.7 \pm 7.3 \mathrm{mg} . \mathrm{L}^{-1}\right.$ and $12.6 \pm 6.0 \mathrm{mg} . \mathrm{L}^{-1}$ respectively) were higher than the one from the rice field $\left(8.5 \pm 6.6 \mathrm{mg} \cdot \mathrm{L}^{-1}\right)$. Lower TOC concentrations were found in the rainy season than in the dry season due to dilution. The results suggest that there is a need for regularly monitoring and putting effort to control organic matters pollution from agricultural runoff in the Red River basin.

Do sử dụng phân bón và thể tích nước tưới lớn, canh tác nông nghiệp đã và đang góp phần đáng kể gây ô nhiễm nguồn nước. Sông Hồng nằm ở Việt Nam, nơi ngành nông nghiệp đóng vai trò quan trọng trong nền kinh tế. Bài báo trình bày kết quả quan trắc hàm lượng cacbon hữu cơ (TOC) bao gồm dạng hòa tan (DOC) và không tan (POC), trong nước chảy tràn từ đất canh tác (rau, hoa, lúa) ở đồng bằng sông Hồng năm 2013 -2014. Kết quả cho thấy DOC thay đổi rất rộng từ 1,0 mg.L-1 đến 37,1 mg.L' 1, trung bình đạt 10,2 $\pm 6,2 \mathrm{mg} \cdot \mathrm{L}^{-1}$ trong khi POC thay đổi từ $0,5 \mathrm{mg} \cdot \mathrm{L}^{-1}$ đến $4,5 \mathrm{mg} \cdot \mathrm{L}^{-1}$, trung bình đạt 1,7 $\pm 0,7 \mathrm{mg} \cdot \mathrm{L}^{-1}$ đối với 104 mẫu nước. TOC từ trồng rau và hoa $\left(11,7 \pm 7,3 \mathrm{mg}\right.$. $\mathrm{L}^{-1}$ và $\left.12,6 \pm 6,0 \mathrm{mg} \cdot \mathrm{L}^{-1}\right)$ cao hơn so với trồng lúa $\left(8,5 \pm 6,6 \mathrm{mg}\right.$. L $\left.^{-1}\right)$. TOC trong mùa mưa thấp hơn so với mùa khô. Cần thường xuyên giám sát và nỗ lực kiểm soát ô nhiễm chất hữu cơ do nước chảy tràn từ đất canh tác ở lưu vực sông Hồng.
\end{abstract}

Keywords: organic matters, agricultural runoff, water pollution, Red River, Vietnam.

\section{Introduction}

Human activities contribute a large amount of pollutants to the water environment, affecting aquatic chemistry and ecosystem (Goel, 2006; Laws, 2018). Among different kinds of pollutants (organic matters, heavy metals, toxic microorganism, nutrients, etc.), organic matters have been popular and drawn much attention in the studies of organic pollution in rivers and lakes in Vietnam and also in the World.

Agricultural runoff is known to be a diffuse source and is very difficult to be controlled. Cultivation is one of the important sources discharging organic matters into river systems (Lilienfein et al., 2001). The development of cultivation relates to the increased utilization of chemical fertilizers, animal manure, large irrigation water, thus causes an important risk of water pollution, especially organic pollution. In receiving water bodies with rich organic matters, dissolved oxygen is usually depleted due to the degradation of organic matters, even to strongly hypoxia. Organic pollutants include pesticides, fertilizers, hydrocarbons, phenols, plasticizers, biphenyls, detergents, oils, greases, pharmaceuticals, proteins and carbohydrates (Rashed, 2013) and toxic organic matters may cause numerous negative effects on water quality and aquatic ecosystem (Javier et al., 2017). Thus, the urgent need is to assess the current state of water quality in order to provide a database for the treatment, protection, and management of water resources, especially for water 
irrigation and water environment. For assessing organic matters in hydrosystem in term of organic pollution, two important variables including dissolved organic carbon (DOC) and particle organic carbon (POC) could be used.

The Red River basin locates in the South East Asian region with a total basin area of about $156.450 \mathrm{~km}^{2}$. Agriculture plays an important role in economic development of this river basin, especially in the Delta area (Le et al., 2015). However, water and soil qualities in this region have been impacted by agricultural activities due to large fertilizer utilization (Nguyen et al., 2012; Nguyen et al., 2014; Vu et al., 2014). Some investigations about nutrients, heavy metals and pesticides have been carried out in the Red River basin but no information existed on the DOC and POC concentrations in agricultural runoff in this region. This study aims to investigate the DOC and POC concentrations in agricultural runoff in the Red River Delta for the period from 2013 - 2014. The results may contribute to the assessment of organic pollution in agricultural runoff in a river basin in South East Asia, the Red River Delta. These results also contribute to the assessment of water quality environment and provide a dataset for water protection and management in Vietnam.

\section{Study site, materials, and methods}

\subsection{Study site}

The Red River is the largest one in North Vietnam. Throughout the whole river catchment, the average air temperature is $14-27^{\circ} \mathrm{C}$; the average humidity is $60-82 \%$ and the average annual rainfall is $1590 \mathrm{~mm}$ of which about $85 \%$ occurs in the rainy season. The population density is not evenly distributed: much lower value was recorded in the upstream basin (<300 inhabitants. $\mathrm{km}^{-2}$ ) whereas very high value was found in the Delta region $\quad>1000$ inhabitants. $\mathrm{km}^{-2}$ ). Rapid population growth has been observed for both rural and urban areas.

The Red River Delta covers a surface area of 14,300 km² and entirely locates in a very flat area (below $3 \mathrm{~m}$ above sea level). In the Red River Delta, agricultural and aquacultural land mainly dominate about $47 \%$ of which, $90 \%\left(6,700 \mathrm{~km}^{2}\right)$ is used for annual crops, $6.6 \%$ for aquaculture and fisheries, 3.1\% for perennial crops, and $0.6 \%$ as pasture area (Luu et al., 2012).

Located in the upstream of the Red River Delta, Hanoi city faces many environmental problems caused by population growth, urbanization, industrial and agricultural development. In the Hanoi suburban areas, Dong Anh district is one of the important districts of Hanoi city, covers a total area of about 18,000 hectares, in which agricultural area accounts for 50\% (9,000 hectares). There are some other important districts such as Tu Liem, Tay Ho where agriculture plays an important role in its economy. In these regions, main and typical agricultural crops such as vegetables, rice, flower plants and fruit trees in some communes Phu Dien, Tay Tuu, Van Noi ... providing foods and vegetables for the whole Hanoi city. The main types of fertilizers used include inorganic fertilizers, organic fertilizers, compost fertilizers, and manure. There are also other types of fertilizers, depending on the needs of each crop. The fertilizer dose for spring rice crop is 10 tons of

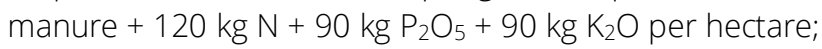
and for winter rice crop: 10 tons of manure $+120 \mathrm{~kg} \mathrm{~N}+$ $60 \mathrm{~kg} \mathrm{P} \mathrm{O}_{5}+60 \mathrm{~kg} \mathrm{~K} 2 \mathrm{O}$ per hectare on the Red River alluvial soil (Bui et al., 2005). In addition, the significant increase (3 folds higher) of the total amount of fertilizer utilization and the change in N:P:K ratio has been observed in Vietnam for the period from 1990 to 2012 (Table 1).

Table 1. Total amount of fertiliser utilization and the change in N:P:K ratio in cultivation in Vietnam (Nguyen, 2013)

\begin{tabular}{llll} 
& 1990 & 2000 & 2012 \\
\hline Total fertilizers $(\mathrm{N}, \mathrm{P}, \mathrm{K}), \mathrm{kg}_{\mathrm{h}} \mathrm{ha}^{-1}$ & 57.8 & 117.8 & 190.0 \\
Ratio N: $\mathrm{P}_{2} \mathrm{O}_{5}: \mathrm{K}_{2} \mathrm{O}$ & $1: 0.12: 0.05$ & $1: 0.44: 0.37$ & $1: 0.51: 0.39$
\end{tabular}

For rice cultivation, a large volume of water is required, averaging about $1500-2500 \mathrm{~m}^{3}$.ha-1. In the spring crop, the total irrigation water for a rice crop is from 4500 - 7000 $\mathrm{m}^{3}$.ha-1. For vegetable cultivation, water demand for irrigation is less than one for rice cultivation, about 1200 $3500 \mathrm{~m}^{3}$.ha-1, depending on the type of plants (MONRE, 2011).

\subsection{Sampling campaigns and water quality analysis.}

\subsubsection{Sampling campaigns and sample treatment}

Sampling campaigns were conducted from January 2013 to July 2014 in dry (from January - April; November December) and rainy (from May to October) seasons in different communes, including: Van Noi and Viet Hung (Dong Anh district), Lien Mac, Tay Tuu and Minh Khai (Tu Liem district) and Quang An (Tay Ho district) in Hanoi city (Figure 1). 


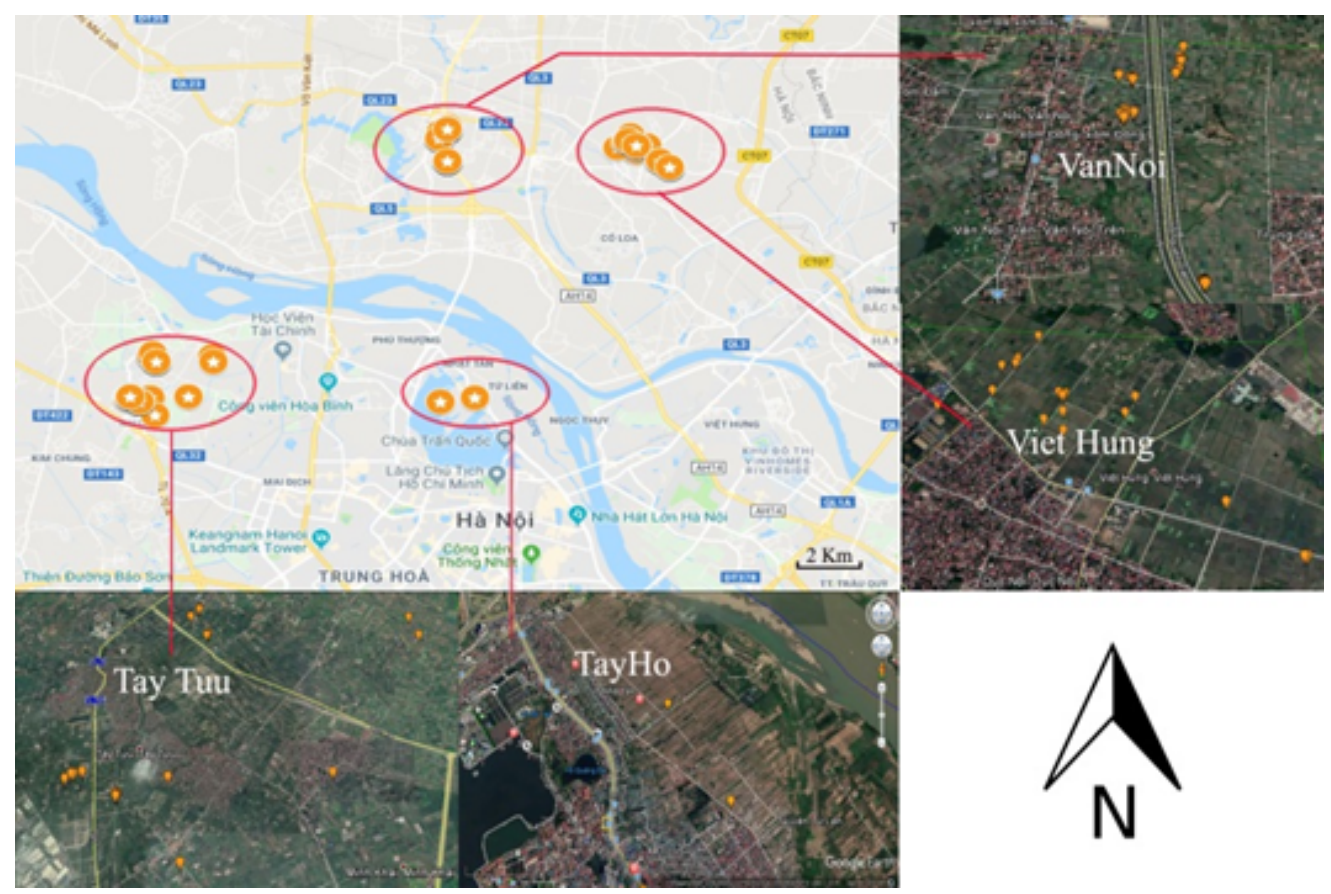

Figure 1. Sites of water sampling in the Red River Delta in the period of 2013 -2014

The agricultural irrigation system is very dense for almost sub-urban cities in the Red River delta, including Hanoi. According to (UBND Hanoi, 2017), there are 11,412 irrigation-drainage canals with a total length of 12,444 km in Hanoi sub-urban. Much more irrigation canals for rice, and less for vegetable and flowers in our study sites.
A total of 104 surface water samples in the agricultural runoff (in small canals/streams) from the separate fields of the three different kinds of plants (flower, vegetable, and rice) in this area were collected (Table 2). Water samples were taken and then stored in accordance with the Vietnam standard TCVN 5999 - 1995 (wastewater sampling guidelines).

\section{Table 2. Water samples collected in Hanoi city in the period from January 2013 to July 2014}

\begin{tabular}{cccl} 
No. & Plant types & Number of water samples & Location \\
\hline 1 & Flowers & 38 & Van Noi (Dong Anh), Tay Tuu (Tu Liem), Quang An (Tay Ho) \\
2 & Vegetables & 43 & Van Noi and Viet Hung (Dong Anh), Lien Mac and Minh Khai (Tu Liem) \\
3 & Rice & 23 & Viet Hung (Dong Anh); Minh Khai (Tu Liem)
\end{tabular}

Water samples (after well mixing) were filtered immediately by a vacuum filtration through a pre-combusted $\left(120^{\circ} \mathrm{C}\right.$ in 2h) glass fiber filterpaper (Whatman GF/F, Ø47mm). All filters and filtrates were kept in a freezer $\left(<-20^{\circ} \mathrm{C}\right)$ after filtration until laboratory analysis.

\subsubsection{Water analysis}

Different physicochemical variables such as temperature $\left({ }^{\circ} \mathrm{C}\right), \mathrm{pH}$, conductivity $\left(\mu \mathrm{S} . \mathrm{cm}^{-1}\right)$, turbidity (NTU), and dissolved oxygen ( $\mathrm{DO}, \mathrm{mgL}^{-1}$ ) were measured in-situ by a water quality checker WQC-22A (TOA, Japan).

For the measurement of TSS, each filter was dried for $1 \mathrm{~h}$ at $105^{\circ} \mathrm{C}$ and then weighed. Taking into account the filtered volume, the increase in weight of the filter represented the total TSS per unit volume $\left(\mathrm{mg} \mathrm{L}^{-1}\right)$.

POC analysis: POC concentrations were estimated on the same filters. Filters were then weighed before and after calcination at $550{ }^{\circ} \mathrm{C}$ for 4 hours. The difference in weight before and after calcination was multiplied by 0.4 to provide an estimation of the POC content (Servais et al., 1995).

DOC analysis: A volume of $30 \mathrm{ml}$ sub-sample of the filtrate was acidified with $35 \mu \mathrm{l} 85 \% \mathrm{H}_{3} \mathrm{PO}_{4}$ acid and then stored at $4{ }^{\circ} \mathrm{C}$ in amber glass bottles until measuring DOC concentrations by using a TOC-VE (Shimadzu, Japan). The samples, standards and blank measurements were repeatedly measured in triplicate.

TOC determination: TOC concentration, an indicator of organic matter, is calculated in this study as the sum of POC and DOC concentrations.

\section{Results}

\subsection{Physico-chemical variables}

The $\mathrm{pH}$ value ranged from 6.0-10.1, of which the $\mathrm{pH}$ average values from the three kinds of plants were quite similar (7.2 - 7.6) (Table 3). These values were within the 
allowable limits of the Vietnam Standard QCVN 08MT:2015/BTNMT. DO content ranged from 0.1 to $5.2 \mathrm{mgL}$ ${ }^{1}$. The DO average was higher for water from the vegetable area $\left(2.8 \pm 1.1 \mathrm{mgL}^{-1}\right)$ and lower from the flowers cultivation $\left(1.9 \pm 1.0 \mathrm{mgL}^{-1}\right)$; Turbidity ranged from $10-680 \mathrm{NTU}$, and higher value of turbidity in water was observed from the flower cultivation (62.1 $\pm 74.0 \mathrm{NTU})$ and the lower from the rice growing area (37.5 \pm 34.4 NTU). The conductivity varied strongly from 22.9 to $1313.0 \mu \mathrm{S} . \mathrm{cm}^{-1}$. TDS ranged largely from 28.8 to $707.0 \mathrm{mg} \cdot \mathrm{L}^{-1}$. The turbidity, TDS and conductivity of the water samples collected from the flower growing area were higher than those of other crops. The suspended solids content in water runoff from agricultural crops largely varied, from 20-648 mg. L $^{-1}$ with an average value of $32.4 \pm 72.3 \mathrm{mg} . \mathrm{L}^{-1}$. The average TSS values in water runoff from the flower, vegetable, and rice fields were 24.0 $\pm 24.6 \mathrm{mg} . \mathrm{L}^{-1}, 45.8 \pm 109.0 \mathrm{mg} \cdot \mathrm{L}^{-1}$ and $18.8 \pm 11.3 \mathrm{mg} \cdot \mathrm{L}^{-1}$, respectively.

Table 3. Values (mean value \pm standard deviation) of different physico-chemical variables of agricultural runoff samples in the Red River Delta in the period 2013 -2014.

\begin{tabular}{llllllll} 
Types of plant & $\begin{array}{l}\mathrm{pH} \\
(-)\end{array}$ & $\begin{array}{l}\text { Temperature } \\
\left({ }^{\circ} \mathrm{C}\right)\end{array}$ & $\begin{array}{l}\text { DO } \\
\left(\mathrm{mg} . \mathrm{L}^{-1}\right)\end{array}$ & $\begin{array}{l}\text { Turbidity } \\
(\mathrm{NTU})\end{array}$ & $\begin{array}{l}\text { Total dissolved } \\
\text { solids }\left(\mathrm{mg} . \mathrm{L}^{-1}\right)\end{array}$ & $\begin{array}{l}\text { Conductivity } \\
\left(\mu \mathrm{\mu S} . \mathrm{cm}^{-1}\right)\end{array}$ & $\begin{array}{l}\text { Total suspended } \\
\text { solids }\left(\mathrm{mg} . \mathrm{L}^{-1}\right)\end{array}$ \\
\hline Flowers & $7.6 \pm 0.5$ & $23.1 \pm 4.4$ & $1.9 \pm 1.0$ & $62.1 \pm 74.0$ & $247.3 \pm 107.2$ & $465.9 \pm 168.0$ & $24.9 \pm 24.6$ \\
Vegetables & $7.6 \pm 0.8$ & $25 \pm 6.2$ & $2.8 \pm 1.1$ & $58.6 \pm 116.4$ & $196.2 \pm 121.8$ & $376.5 \pm 236.9$ & $45.8 \pm 109.0$ \\
Rice & $7.2 \pm 0.5$ & $24.1 \pm 4.2$ & $2.2 \pm 0.7$ & $37.5 \pm 34.4$ & $161.7 \pm 87.7$ & $333.2 \pm 180.8$ & $18.8 \pm 11.3$ \\
QCVN 08 col. B1 * & $\geq 4$ & $5.5-9$ & - & - & - & - & 50
\end{tabular}

*QCVN 08-MT:2015/BTNMT column B1: It is applied to surface water used for irrigation or for other uses with similar water quality requirements given in column B2 (water navigation and other purposes with low quality water requirements) (MONRE, 2015).

\subsection{DOC and POC concentrations}

DOC concentrations in water runoff from three kinds of plant cultivation largely varied from 1.0 - $37.1 \mathrm{mgL}^{-1}$ with a mean value of $10.2 \pm 6.2 \mathrm{mg} . \mathrm{L}^{-1}$ for a total of 104 samples. DOC concentrations averaged $11.2 \pm 5.8,10.0 \pm 6.7$, and $9.0 \pm 6.0 \mathrm{mgL}^{-1}$ for water samples from flower, vegetable and rice fields, respectively (Table 4). The POC contents of water runoff from three kinds of plant cultivation varied from 0.5 to $4.5 \mathrm{mgL}^{-1}$ with a mean value of $1.7 \pm 0.7 \mathrm{mgC.L}$ ${ }^{1}$ for the total of 104 samples. The average values of POC contents from flowers, vegetables and rice fields were 1.7 $\pm 0.6,1.8 \pm 0.8$ and $1.7 \pm 0.5 \mathrm{mgL}^{-1}$, respectively. Unfortunately, no allowed value existed in the Vietnam standards for both DOC and POC concentrations in surface water.

\section{Discussion}

\subsection{Seasonal variation of DOC and POC concentrations}

As known, POC and DOC concentrations in small streams or river water mainly depend on many factors in the basin such as climate regime - hydrology, erosion and leaching rates, vegetation, cultivation, minerals as well as the structure of soil and rock in a watershed (Ludwig et al., 1996). In this study, the mean value of DOC concentrations from the rice field was lower than the ones from flower and vegetable fields. (Table 4). The DOC values in this study were much higher than the ones found in agricultural irrigation water (5.3 $\mathrm{mgL}^{-1}$ ) in Gyeongnam, South Korea (Lee et al., 2013), probably due to higher fertilizer application in our sites. These DOC values were also much higher than the one observed for the Red River water at Chuong Duong bridge in Hanoi (3.60 mg. L $\mathrm{L}^{-1}$ in the range of

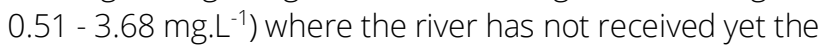
whole wastewater of the Hanoi city and the river discharge was quite high (1956 $\pm 1356 \mathrm{~m}^{3} \cdot \mathrm{s}^{-1}$ ) (Le et al., 2012).

Table 4. The average and min-max concentrations of DOC, POC, TOC, TSS in agricultural runoff samples in the Red River Delta

\begin{tabular}{|c|c|c|c|c|c|}
\hline Type & Season & $\mathrm{POC}, \mathrm{mg} \cdot \mathrm{L}^{-1}$ & $\mathrm{DOC}, \mathrm{mg} \cdot \mathrm{L}^{-1}$ & TOC, mg.L $\mathrm{L}^{-1}$ & Ratio DOC/POC \\
\hline \multirow[t]{3}{*}{ Flowers } & whole period & $1.7 \pm 0.6$ & $11.2 \pm 5.8$ & $12.9 \pm 6.1$ & $7.1 \pm 3.9$ \\
\hline & dry season & $1.5 \pm 0.5$ & $12.3 \pm 3.6$ & $13.8 \pm 3.7$ & $8.1 \pm 4.1$ \\
\hline & rainy season & $1.9 \pm 0.7$ & $10.2 \pm 7.2$ & $12.0 \pm 7.6$ & $5.5 \pm 2.5$ \\
\hline \multirow[t]{3}{*}{ Vegetables } & whole period & $1.8 \pm 0.8$ & $10.0 \pm 6.7$ & $11.7 \pm 7.3$ & $6.5 \pm 4.9$ \\
\hline & dry season & $1.9 \pm 1.0$ & $11.8 \pm 7.3$ & $13.4 \pm 8.0$ & $6.3 \pm 6.2$ \\
\hline & rainy season & $1.8 \pm 0.7$ & $7.9 \pm 5.4$ & $9.6 \pm 5.7$ & $4.5 \pm 2.7$ \\
\hline \multirow[t]{3}{*}{ Rice } & whole period & $1.7 \pm 0.5$ & $9.0 \pm 6.0$ & $8.5 \pm 6.6$ & $4.1 \pm 3.9$ \\
\hline & dry season & $1.8 \pm 0.5$ & $16.8 \pm 1.1$ & $10.2 \pm 8.9$ & $9.1 \pm 5.1$ \\
\hline & rainy season & $1.6 \pm 0.5$ & $5.1 \pm 2.3$ & $6.7 \pm 2.5$ & $3.2 \pm 2.2$ \\
\hline
\end{tabular}


Our observation results showed that the average values of POC contents from flower, vegetable, and rice fields were quite similar, equal to $1.7 \pm 0.6 \mathrm{mg} \cdot \mathrm{L}^{-1}, 1.8 \pm 0.8 \mathrm{mgL}^{-1}$ and $1.7 \pm 0.5 \mathrm{mg} . \mathrm{L}^{-1}$ respectively, which is approximately the one reported for the Red River $\left(1.73 \mathrm{mg} . \mathrm{L}^{-1}\right)$ in Hanoi (Le et al., 2012).

The TOC concentration in the water runoff from the three

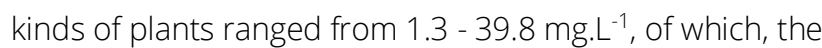
TOC in water from the fields of vegetables and flowers $\left(11.7 \pm 7.3 \mathrm{mg} \cdot \mathrm{L}^{-1}\right.$ and $12.6 \pm 6.0 \mathrm{mg} \cdot \mathrm{L}^{-1}$ respectively) was higher than that from rice fields $\left(8.5 \pm 6.6 \mathrm{mg} . \mathrm{L}^{-1}\right)$. Higher values of TOC concentrations from the fields of vegetables and flowers than from rice field probably reflect the difference in cultivation technique, fertilizer utilization and irrigation water volume for the three kinds of plant. For flowers and vegetable cultivation, surface soils are much more affected and much lower irrigation water required than the ones of rice field. A previous study observed water quality from agricultural region in the Phu Dien and Tay Tuu communes (Tu Liem district, Hanoi city) in 2011-2014 and revealed that a high range of chemical oxygen demand (COD) concentrations (5 - $332 \mathrm{mg} . \mathrm{L}^{-1}$, averaging $43 \mathrm{mg} . \mathrm{L}^{-1}$ ) in agricultural runoff from the flower and vegetable fields was observed (Vu and al., 2014). The mean value of COD (43 mg. L $^{-1}$ ) was higher than the Vietnamese standard limits for surface water, QCVN 08-MT:2008/BTNMT column B. Our results are consisting with this previous study.

These mean TOC values were much higher than the one (5.7 mg. $\mathrm{L}^{-1}$ ) found in irrigation water in Gyeongnam province, South Korea (Lee et al., 2013), or in the Red River water (5.3 mg. L $^{-1}$ ) in Hanoi (Le et al., 2012). Le et al., (2017) suggested that organic carbon in the Red River water is mainly derived from erosion and soil leaching in the basin. Our results provide further evidence that organic matters from agricultural runoff play an important role in contributing organic carbon of the Red River water. Indeed, within two forms (dissolved and particulate) of organic carbon, DOC may play more important than POC for contributing to the carbon concentrations in the Red River water, especially in the dry season.

There are many factors affecting TOC (including DOC and POC) contents in agricultural runoff of the Red River basin. For example, the decomposition of plants, animal waste, chemical fertilizers, pesticides, soil fertility, rainfall, and air temperature, etc... However, it cannot be ignored that the greatest impact on water quality comes mainly from fertilizers and pesticides used for different crops (Pathak et al., 2015). A previous study indicated that more than $55 \%$ of chemical fertilizers applied to the agricultural soil could not be used by the crop (Truong Hop Tac, 2009). The excess of fertilizer utilization is known that it was partially retained in the soil, partly washed-off into the groundwater, partially evaporated in functioning of air temperature or nitrifying reaction that pollutes the air, whereas the rest was reached to the surface water (ponds, lakes, rivers, and streams), causing surface water pollution. Previous study (Vu et al., 2014) also pointed out the high nutrients in agricultural runoff of vegetable and flower fields in Tay Tuu communes (Tu Liem district, Hanoi city): an average ammonium concentration of $2.2 \mathrm{mgN}^{-1}{ }^{-1}$ which was 4.4 times higher than the Vietnamese standard and average of phosphate concentration of $0.73 \mathrm{mgP.L} \mathrm{L}^{-1}$ which was 2.4 times higher than the allowed value of the QCVN 08-MT:2008/BTNMT column B. The authors emphasized the impact of the excess of fertilization utilization in agricultural land on surface water quality (Vu et al., 2014).

Our observations showed that there was a clear seasonal variation of DOC concentrations in agricultural runoff in the Red River Delta whereas POC concentrations showed a complex seasonal variation. DOC contents in water from all three kinds of plants in the rainy season were lower than the ones in the dry season ( $p<0.05$ ), probably due to dilution process and also related with high organic fertilizer utilization for the crop required. POC showed higher concentrations for flower field but lower concentrations for rice and vegetable fields in the rainy season probably reflect higher organic fertilizer utilization and cultivation technique for flower crop. The TOC concentrations followed the same trend of seasonal variation of DOC concentration. Thus, lower TOC concentrations were found in the rainy season than in the dry season in agricultural runoff from all three kinds of plants: flowers (12.0 $\pm 7.6 \mathrm{mg} . \mathrm{L}^{-1}$ vs. $\left.13.8 \pm 3.7 \mathrm{mg} . \mathrm{L}^{-1}\right)$, vegetables $(9.6 \pm$ $5.7 \mathrm{mg} . \mathrm{L}^{-1}$ vs. $\left.13.4 \pm 8.0 \mathrm{mg} . \mathrm{L}^{-1}\right)$ and rice $\left(6.7 \pm 2.5 \mathrm{mg} . \mathrm{L}^{-1} \mathrm{vs}\right.$. $10.2 \pm 8.9 \mathrm{mg} \cdot \mathrm{L}^{-1}$ ) fields (Table 4).

\subsection{Dissolved vs. particulate organic carbon (DOC/POC ratio)}

The ratio of DOC/POC contents is often considered in evaluations of organic carbon in water environments. In addition, the value of DOC/POC ratio may characterize the environment and hydrology of a drainage basin (Meybeck, 1982). Huang et al. (2017) reported that the high DOC/POC ratios indicate that organic carbon is mostly stored in dissolved form. A value of 1.5 was reported for global mean DOC/POC ratio but this value may be different for the river system (Meybeck, 1982). In our case, the DOC/POC ratio in water runoff from three plants fields in this study varied between 2.0 - 9.1, averaging 6.1 for all 104 water samples observed. The mean value of DOC/POC ratio in water runoff was found highest in the flower field (6.6), and lowest in the rice field (5.3). The DOC/POC ratios in this study were still far lower than the ones of highly polluted rivers (> 20) however they were much higher than the ones of mountainous streams or for rivers that cross pasture land (<1) (Malcolm and Durum, 1976).

The DOC/POC ratio was much higher in the dry season than in the rainy season in all water samples from three kinds of plant cultivation (Figure 2). This may be explained by the effect of water dilution in the rainy season. 


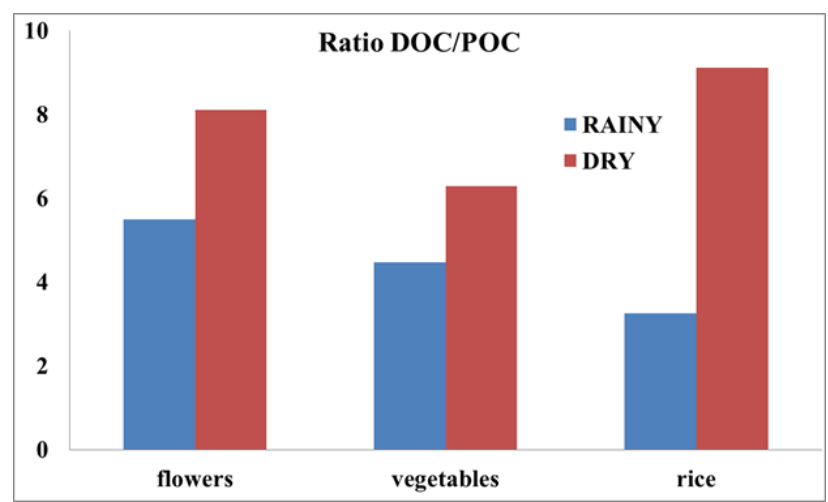

Figure 2. DOC/POC ratio in water runoff from the three kinds of plants in the Red River Delta in the period 2013 2014.

The results showed that proportion of DOC to TOC (DOC/TOC) in water runoff from the three kinds of plant fields was higher than 80\% (Figure 3), indicating that a large proportion of organic matters in agricultural runoff in the Red River Delta were under soluble form. In addition, there was no significant difference between \%DOC and \%POC for different kinds of water runoff from rice, flower and vegetable fields in our study (Figure 3).

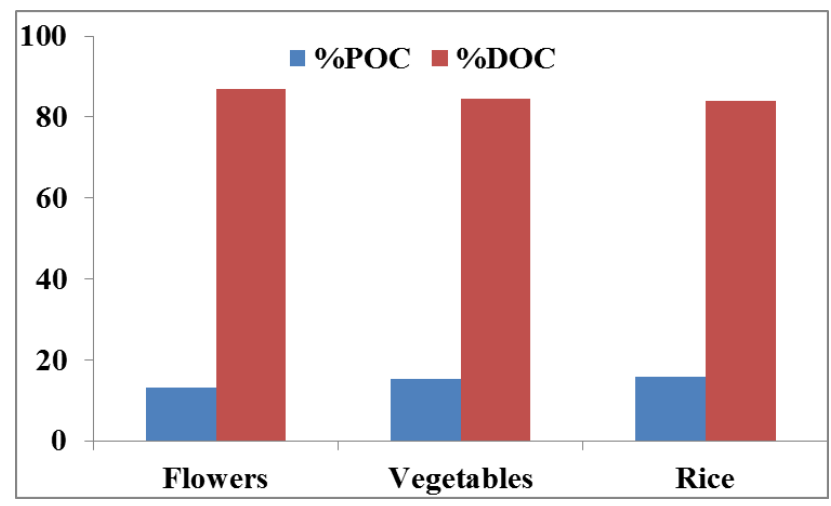

Figure 3. percentage of DOC and POC in water runoff from the three kinds of plants in the Red River Delta in the period $2013-2014$

For streams and rivers receiving untreated wastewater, organic matters in wastewater could be decomposed by microorganisms, and this decomposition process often causes an oxygen deficiency in water (Garnier et al., 2001). Oxygen levels could be reduced down to a very low value and it is unsuitable for the life of aquatic organisms, especially fish. This is true for this study when considering some low values of DO in streams/canals in the agricultural region like the Red River Delta. Our results revealed that untreated agricultural wastewater discharged into the lake/river system cause serious organic pollution to the received aquatic ecosystems. In the other hand, noted that these canals where water sampled in our study may provide irrigation water for other agricultural regions. Therefore, it is necessary to pay more attention to agricultural runoff observation for environmental management and protection purposes.

\section{Conclusion}

The observation results of 104 water samples from agricultural runoff from rice, flowers, and vegetables in the Red River Delta showed that: $\mathrm{pH}(6.0$ - 10.1); DO (0.1 - 5.2 mg. $\left.\mathrm{L}^{-1}\right)$, conductivity (22.9 to $\left.1313.0 \mu \mathrm{S} . \mathrm{cm}^{-1}\right)$ and turbidity $\left(10\right.$ - 680 NTU mg.L $\left.{ }^{-1}\right)$. The results showed that DOC concentrations varied in a high range from $1.0 \mathrm{mg} . \mathrm{L}^{-1}$ to $37.1 \mathrm{mg} . \mathrm{L}^{-1}$, averaging $10.2 \pm 6.2 \mathrm{mg} . \mathrm{L}^{-1}$ whereas POC concentrations varied from 0.5 to $4.5 \mathrm{mg} . \mathrm{L}^{-1}$, averaging 1.7 $\pm 0.7 \mathrm{mg} . \mathrm{L}^{-1}$ for a total 104 samples observed. TOC concentrations in water from the vegetable and flower fields $\left(11.7 \pm 7.3 \mathrm{mg} . \mathrm{L}^{-1}\right.$ and $12.6 \pm 6.0 \mathrm{mg} . \mathrm{L}^{-1}$ respectively) were slightly higher than the one from the rice field ( $8.5 \pm$ $\left.6.6 \mathrm{mg} \cdot \mathrm{L}^{-1}\right)$.

DOC concentrations showed a significant seasonal variation for all three kinds of water samples with lower values in the rainy season, showing the importance of the dilution process in the Red River Delta. The DOC/POC ratio varied from 2.0-8.2, averaging 6.1 for all 104 water samples indicating a soluble form of organic matters was mainly dominated in agricultural runoff in the Red River Delta.

The results suggest that there is a need for regularly monitoring and putting effort to control organic matters pollution from agricultural runoff in the Red River basin in particular or other river basins in Vietnam. In addition, the results revealed that the excess of fertilizer utilization in agricultural fields has accelerated organic matter pollution in the Red River basin. Thus a warning about this question should be given to local farmers.

\section{Acknowledgment}

The authors thank the financial supports of the NAFOSTED-Vietnam for the project No 105.08-2018.317 (Dr. Le Thi Phuong Quynh).

\section{References}

[1] Huang, C., liang, Q., Yao, L., Yang, H., Lin, C., Huang, T., Zhu, A.-X., \& Zhang, Y. (2018). Variation pattern of particulate organic carbon and nitrogen in oceans and inland waters. Biogeosciences, 15, 1827-1841.

[2] Garnier, J., Servais, P., Billen, G., Akopian, M. \& Brion, N. (2001). Lower Seine river and estuary (France): carbon and oxygen budgets during low flow. Estuaries, 24, 964-976.

[3] Le, T.P.Q., Nguyen, T.M.H., Nguyen, T.B.N., Duong, T.T. \& Ho, T.C. (2012). Preliminary results of carbon contents in the water environment of the Red river system. Journal of Science and Technology, 50(3B), 47-52 (in Vietnamese).

[4] Le, T. P. Q., Billen, G., Garnier, J. \& Chau, V.M. (2015). Long-term biogeochemical functioning of the Red River (Vietnam): past and present situations. Regional 
Environmental Change, 15(2), 329-339.

[5] Le, T.P.Q., Dao, V.N., Rochelle-Newall, E., Garnier, J., Lu, X.X., Billen, G., Duong, T.T., Ho T.C., Etcheber, H., Nguyen, T.M.H., Nguyen, T.B.N., Le, N.D. \& Pham, Q.L. (2017). Total organic carbon fluxes of the Red River system (Vietnam). Earth Surface Processes and Landforms, 42(9), 1329-1341.

[6] Lilienfein, J., Wilcke, W., Thomas, R., Vilela, L., Lima, S. d. C., \& Zech, W. (2001). Effects of Pinus caribaea forests on the C, N, P, and S status of Brazilian savanna Oxisols. Forest Ecology and Management, 147(2-3), 171-182. .

[7] Nguyen, T.M.H., Le, T.P.Q., Duong, T.T., \& Ho, T.C. (2012). Preliminary result of the DOC/POC ratio in the water environment of the Red river system, Vietnam. Soil Science, 39, 60-62 (in Vietnamese).

[8] Nghiem, X.A., Le, T.P.Q., Vu, H.H., Duong, T.T. \& Dang, D.K. (2010). Organic pollution in the Day-Nhue river system: Present situation and cause. Vietnam Journal of Science and Technology, 48(4A), 376-382 (in Vietnamese).

[9] Rashed, M.N. (2013). Adsorption Technique for the Removal of Organic Pollutants from Water and Wastewater, Organic Pollutants, M. Nageeb Rashed, IntechOpen, doi: 10.5772/54048.

[10] Lee, S.T., Lee, Y.H., Hong, K.P., Lee, S.D., Kim, M.K., Park, J.H. and Seo, D.C. (2013). Comparison of BOD, COD, TOC and DOC as the indicator of organic matter pollution of agricultural surface water in Gyeongnam Province Korean. J. Soil Sci. Fert, 46(5), 327-332.

[11] Vu, D.A., Le, T.P.Q., Nguyen, T.B.N., Pham, Q.L., Seilder, C. \& Phung, T.X.B. (2014). Wastewater quality of the agricultural region (vegetables- flowers-fruit plants) at Phu Dien and Tay Tuu wards (Hanoi), Journal Science and Technology Development, 17(M2/2014), 13-21 (in Vietnamese).

[12] Vu, H.H. (2011). Some findings of the study on the issue of water pollution and protection of water quality of Nam Thai Binh irrigation system. Journal of Water Resources \& Environment Engineering, 33, 4046 (in Vietnamese).

[13] Luu, T.N.M., Garnier, J., Billen, G., Le, T.P.Q., Némery, J., Orange, D. \& Le, L.A. (2012). N, P, Si budgets for the Red River Delta (Northern Vietnam): How the delta affects river nutrient deliveries to the sea. Biogeochemistry, 107(1-3), 241-259.

[14] Ludwig, W., Probst, J.L., \& Kempe, S., (1996). Predicting the oceanic input of organic carbon by continental erosion. Global Biogeochemical Cycles, 10, 23-41.

[15] Meybeck, M., (1982). Carbon, nitrogen and phosphorus transport by World rivers. Am. J. Sci. 282, 401-405.

[16] Malcolm, R.L., \& Durum, W.H. (1976). Organic carbon and nitrogen concentrations and annual organic load of six selected rivers of the United States. Geological Survey Water-Supply Paper 1817-F. 21 pp.

[17] Le, T.P.Q., Le, N.D., Dao, V.N., Rochelle-Newall, E., Marchand, C., Nguyen, T.M.H. \& Duong, T.T. (2018). Change in carbon flux of the Red River (Vietnam). Journal of Environmental Earth Science. 77: 658.

[18] Nguyen, T.M.H, Le, T.P.Q., Nguyen, T.B.N, Duong, T.T., Seilder, C. \& Kandler, M. (2012). Heavy metals contents in soil and water environment from the agricultural areas (flowers - vegetables - fruits) in Phu Dien and Tay Tuu districts (Hanoi). Vietnam Journal of Science and Technology. 50(4), 491-496 (in Vietnamese).

[19] Nguyen, T.B.N., Le, T.P.Q., Nguyen, B.T., Nguyen, T.M.H., Vu, D.A., Duong, T.T. \& Ho, T.C. (2014). Agricultural wastewater quality of a vegetable growing area Van Noi commune, Dong Anh district, Hanoi city. Vietnam Agriculture and Rural development, 21, 6571 (in Vietnamese).

[20] Servais, P., Barillier, A. \& Garnier, J. (1995). Determination of the biodegradable fraction of dissolved and particulate organic carbon in waters. Int J Limnol., 31(1), 75-80.

[21] Nguyen. V.B. (2013). Improving the efficiency of fertilizer use in Vietnam. The report was presented at the National Fertilizer Conference on 5-3-2013. Can Tho City, Vietnam (in Vietnamese).

[22] Javier, M.S., Zadeh, S. M., Turral, H. \& Burke, J. (2017). Water pollution from agriculture: a global review. Executive summary. Rome, Italy: FAO; Colombo, Sri Lanka: International Water Management Institute (IWMI). CGIAR Research Program on Water, Land and Ecosystems (WLE). 35p. Retrieved from http://www.fao.org/3/a-i7754e.pdf.

[23] Rice, E.W. (2012) Standard methods for examination of water and wastewater, 22nd ed. / prepared and published jointly by American Public Health Association, American Water Works Association, Water Environment Federation joint editorial board, Eugene W. Rice ... [et al.] managing editor, Laura Bridgewater; American Water Works Association: Washington, D.C., ISBN 9780875530130.

[24] Bui, H.H., Nguyen, T.T. and collaborators. (2005). Fertilizer application for the system of rice crops in the Red River Delta. Results of scientific research. Book No.4. The 35th anniversary of establishment (1969-2004). Agricultural Publishing House, Hanoi (in Vietnamese).

[25] Goel, P.K. (2006). Water Pollution - Causes, Effects and Control (Rev. 2nd ed.). New Delhi: New Age International. ISBN 978-81-224-1839-2.

[26] Laws, E.A. (2017). Aquatic Pollution: An Introductory Text (4th ed.). Hoboken, NJ USA: John Wiley \& Sons Inc. ISBN 9781119304500. 
[27] MONRE (2011). Vietnam Ministry of Natural Resources and Environment. TCVN: Vietnam standard 8641:2011. Irrigation engineering works to irrigate food crops (in Vietnamese).

[28] MONRE (2015). Vietnam Ministry of Natural Resource and Environment, National technical regulation on the surface water quality QCVN 08:2015/BTNMT (in Vietnamese).

[29] Ittekkot, V. \& Laane, R.W.P.M. (2002). Chapter 10: Fate of Riverine Particulate Organic Matter. In E. Degens, S. Kempe, J. Richy (Ed), SCOPE 42- Biogeochemistry of Major World Rivers (pp.233-243). Publisher: John Wiley.

[30] Pathak, H., Bhatt, B.P. \& Gupta, S. K. (2015). Chapter 4: water pollution and agriculture. In H. Pathak, B.P. Bhatt, and S. K. Gupta State of Indian agriculturewater (pp. 39-45). National academy of agricultural sciences, New Delhi, India.

[31] Agroviet-1/6/2009 (2009). The effect of using fertilizers on the environment. E-portal of the Ministry of Agriculture and Rural Development. Retrieved November 20, 2018, retrieved from https://www.mard.gov.vn/Pages/anh-huong-cua-viecsu-dung-phan-bon-den-moi-truong-417.aspx (in Vietnamese).

[32] UBND Hanoi. Hanoi People's committee (2017). Strictly handle the infringement of the ordinance Exploitation and protection of irrigation works/system" as soon as it occurs. Retrieved: February 26, 2017, retrieved from https://hanoi.gov.vn/tintuc_sukien//hn/ZVOm7e3VDMRM/7320/2791054/7/xu-lynghiem-vi-pham-phap-lenh-khai-thac-va-bao-vecong-trinh-thuy-loi-ngay-khi-phatsinh.html;jsessionid=PW1 IDusCbBGkP4IxpoJCIgjC.ap p2 (in Vietnamese).

[33] VGP (Socialist Republic of Vietnam) (2017). Strengthen the management of the fertilizer market. Retrieved November 21, 2018, retrieved from http://baochinhphu.vn/Thi-truong/Tang-cuong-quanly-thi-truong-phan-bon/319664.vgp. (in Vietnamese). 